http://ejournal.undip.ac.id/index.php/kapal

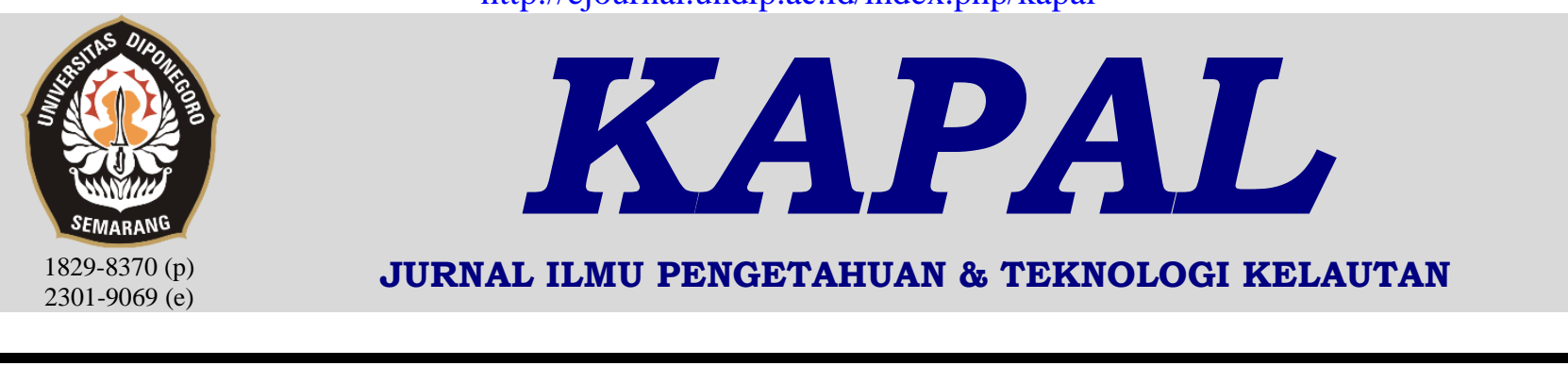

\title{
Pengaruh Suhu Kempa Terhadap Kualitas Balok Laminasi Kombinasi Bambu Petung Dengan Bambu Apus Untuk Komponen Kapal
}

\author{
Parlindungan Manik ${ }^{\left.l)^{*}\right)}$, Sarjito Joko Sisworo ${ }^{l)}$, Guntur Sadewo ${ }^{l)}$ \\ ${ }^{1)}$ Departemen Teknik Perkapalan, Fakultas Teknik, Universitas Diponegoro \\ Jl. Prof. Soedarto, SH, Kampus Undip Tembalang, Semarang, Indonesia 50275
}

\begin{abstract}
Abstrak
Penggunaan kayu untuk industri terus mengalami peningkatan baik untuk pemakain structural maupun non structural. Permintaan akan kayu tersebut tidak dapat terpenuhi akibat kurangnya kualitas kayu yang baik. Disisi lain pemanfaatan bambu selama ini belum optimal walapun hasil beberapa penelitian menunjukan bahwa bamboo memiliki kekuatan dan keunggulan dibandingkan dengan material bangunan lainya. Maka dilakukan penelitian tentang laminasi bambu. Penelitian ini bertujuan untuk mengetahui nilai kadar air, kerapatan, kuat Tarik, MOR, modulus elastisitas dari laminasi bambu petung kombinasi bambu apus akibat pengaruh suhu kempa $\left(80^{\circ} \mathrm{C}, 100^{\circ} \mathrm{C}, 120^{\circ} \mathrm{C}, 130^{\circ} \mathrm{C}, 140^{\circ} \mathrm{C}\right)$. Dalam penelitian ini dibuat balok laminasi bambu petung kombinasi bambu apus untuk uji kuat tarik mengacu pada standar SNI 03-3399-1994 dan uji kuat lentur mengacu pada standar SNI 03-3960-1995. Hasil penelitian untuk untuk pengujian Tarik memiliki kadar air rata-rata $11.81 \%$, berat jenis terbesar $0.7294 \mathrm{~g} / \mathrm{cm}^{3}$ untuk suhu kempa $140^{\circ} \mathrm{C}$, kekuatan tarik rata-rata sebesar $97.84 \mathrm{Mpa}$ untuk suhu kempa $120^{\circ} \mathrm{C}$. untuk laminasi bambu untuk pengujian lentur memiliki nilai kadar air rata - rata sebesar $11.58 \%$, berat jenis sebesar $0.7219 \mathrm{~g} / \mathrm{cm}^{3}$ untuk suhu kempa $140^{\circ} \mathrm{C}$, modulus of repture sebesar 101.59 Mpa untuk suhu kempa $140^{\circ} \mathrm{C}$, modulus elastisitas $9171 \mathrm{Mpa}$ untuk suhu kempa $140^{\circ} \mathrm{C}$.
\end{abstract}

Copyright (C) 2017, KAPAL, 1829-8370(p), 2301-9069(e)

Kata Kunci : laminasi, bambu apus, bambu petung, suhu kempa, kuat tarik, kuat lentur.

\section{PENDAHULAN}

Melihat kondisi dimasa sekarang ini, bahwa untuk mendapatkan kayu mutu tinggi semakin sulit, terlebih untuk mendapatkan mutu kayu dengan kualitas yang baik akan menghabiskan biaya yang besar, maka salah satu cara adalah dengan teknik laminasi. Bila jenis bambu petung dan bambu lainnya dimanfaatkan sebagai balok laminasi, maka diharapkan dapat menghemat penggunan kayu kualitas tinggi dan biaya yang dikeluarkan lebih murah.

Keadaan ini ditunjang oleh kenyataan bahwa Indonesia kaya akan jenis bambu yang berpotensi ekonomi baik secara lingkup local, nasional

*) Penulis Korespondensi :

Email : parlin1974@yahoo.com. maupun internasional. Potensi bambu di Indonesia meliputi lebih dari 143 jenis bambu dan 9 jenis diantaranya merupakan bambu yang hidup endemik dijawa [1].

Dari berbagai pengujian bahan di laboratorium, diketahui bahwa bambu mempunyai kekuatan tarik sangat tinggi, mendekati kuat tarik baja struktural. Selain itu bambu berbentuk pipa, sehingga momen lembamnya besar, tetapi ringan.Dengan adanya ruas-ruas maka bahaya tekuk lokal cukup rendah dan sifat bambu yang ringan dan lentur [2].

Balok laminasi atau dikenal dengan sebagai glulam (glued-laminated timber) merupakan salah satu produk kayu rekayasa tertua. Balok laminasi terbuat dari dua atau lebih kayu gergajian yang direkat dengan arah sejajar satu sama lain, berbentuk lurus atau lengkung terdiri peruntukanya 
[3]. Pada dasarnya balok laminasi adalah produk yang dihasilkan dengan menyusun sejumlah papan atau lamina diatas satu dengan yang lainya danmerekatkanya sehingga membentuk penampang balok yang diinginkan [4].

Berdasarkan posisi pembebanan, balok laminasi dibedakan menjadi balok laminasi horizontal dan vertical. Sedangkan berdasarkan penampangnya balok laminasi dibagi menjadi balok I, balok T, balok I ganda, balok pipa/kotak dan stressed-skin panel. Bentuk-bentuk balok laminasiterdiri atas balok laminasi lurus dan lengkung yang masing-masing memiliki banyak variasi.

Penelitian terdahulu mengenai laminasi bambu petung telah dilakukan dengan cara mengkombinasikan bambu tersebut dengan kayu keruing [7], kayu meranti [8] dan kayu kelapa (glugu) [9]. Selain bambu, penelitian mengenai kekuatan sambungan laminasi kayu pada kapal tradisional laban juga telah dilakukan [10].

Adapun tujuan dari penelitian ini adalah untuk mengetahui nilai kadar air, kerapatan, kuat Tarik, MOR, modulus elastisitas dari laminasi bambu petung kombinasi bambu apus akibat pengaruh suhu kempa sebagai bentuk inovasi untuk mengganti bahan baku kayu yang selama ini digunakan pada kapal kayu.

\section{METODE}

Penelitian ini difokuskan untuk mencari nilai kekuatan lenturdankekuatanTarikdaripaduanbamboopetung danbambooapus setelah proses laminasidandiuji.

1. Parameter Tetap

$>$ Balok Laminasi

Balok laminasi glulam yang terdiri dari bambooapus dan bambu petung yang direkatkan menggunakan perekat Phenol Formaldehyde.

> Dimensi ukuran menurut SNI 03- 3960- 1995 tentang pengujian lentur bambu di laboratorium. Pengujian ini menggunakan SNI 03- 3960- 1995 mengenai :Metode Pengujian Modulus Elastisitas Lentur Bambu di Laboratorium. Dalam pengujian ini menggunakan prosedur pembebanan tegak lurus dengan garis rekatan dengan pembebanan terpusat. Dengan ukurun benda uji $50 \times 50$ x460 mm. [5]

$>$ Dimensi ukuran menurut SNI 03-3399-1994 tentang pengujian tarik bambudi laboratorium. Pengujian ini menggunakan standar SNI 033399-1994 mengenai : Metode Pengujian Kuat Tarik Bambu di Laboratorium. [6]

2. Parameter Perubahan
Parameter perubahan ditentukan akibat perlakuan suhu kempa pada balok laminasi sebesar $80^{\circ} \mathrm{C}, 100^{\circ} \mathrm{C}, 120^{\circ} \mathrm{C}$, dan $140^{\circ} \mathrm{C}$.

\section{HASIL DAN PEMBAHASAN \\ 3.1. Kadar Air}

Kadar air dari bambu petung dan bambu apus mempunyai pengaruh signifikan terhadap sifat fisik dan mekanik. Kadar air berpengaruh pada bambu laminasi. Menggunakan standarisasi ISO 22157-I-2004 dengan benda uji t x $25 \times 25 \mathrm{~mm}^{[6]}$. Kadar air yang baik $12 \%$. Kadar air bambu dapat dihitung dengan menggunakan persamaan dibawah ini.

$$
\mathrm{Mc}-\frac{\mathrm{m}-m o}{m o} \times 100 \%
$$

Dengan Mc: kadar air (\%); m: massa benda uji sebelum kering oven (gram); mo: massa benda uji setelah kering oven (gram).

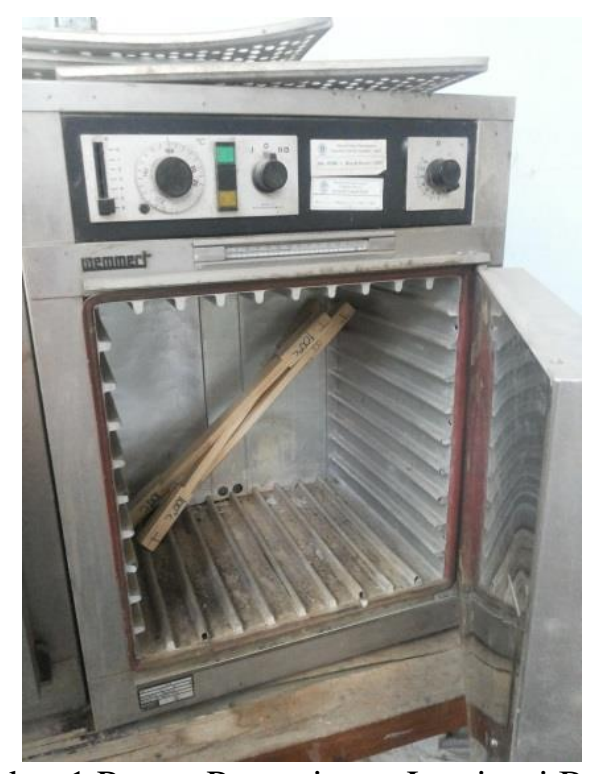

Gambar 1.Proses Pengeringan Laminasi Bambu Menggunakan Oven

\subsection{Kadar Air Spesimen Pengujian Tarik}

Hasil perhitungan kadar air bambu laminasi rata - rata berkisar dari $11.33 \%-12.40 \%$ seperti terlihat pada gambar 4.1 Kadar air rata-rata laminasi bambu terendah pada suhu kempa $140^{\circ} \mathrm{C}$ dan tertinggi pada suhu kempa $80^{\circ} \mathrm{C}$ dengan lama waktu kempa 15 menit. Tetapi kadar air laminasi yang dikempa pada suhu $140^{\circ} \mathrm{C}$, relative tidak jauh berbeda berbeda dengan kadar air laminasi yang dikempa pada suhu $130^{\circ} \mathrm{C}$.

Hal ini menunjukan bahwa semakin tinggi suhu yang digunakan, kadar air laminasi semakin berkurang, tetapi penguranganya tidak efektif lagi jika terlah mencapai titk tertentu. 


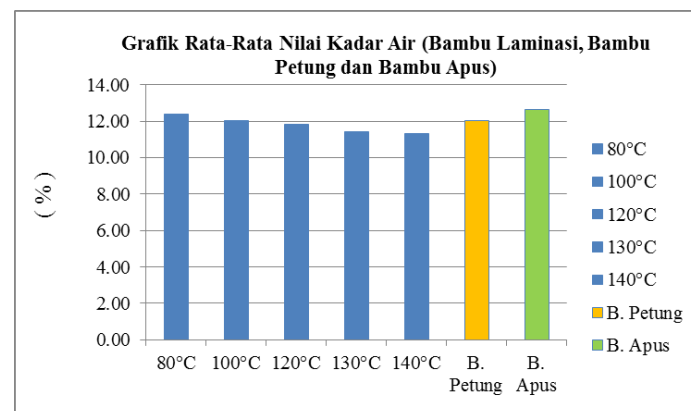

Gambar 2.Nilai rata - rata Kadar Air Pengujian Tarik

Nilai kadar air untuk bambu petung kering oven sebesar $12.05 \%$. Nilai kadar apus kering oven sebesar $12.63 \%$.

Tabel 1. Nilai Kadar Air Laminasi Bambu

\begin{tabular}{|c|c|c|c|c|c|c|}
\hline \multirow[b]{2}{*}{$\mathrm{N}$} & \multicolumn{6}{|c|}{ Ukuran Lamina ( $460 \times 25 \times 25 \mathrm{~mm})$} \\
\hline & Kode Uji & Berat Awal (gr) & berat akhir (gr) & volume $\left(\mathrm{cm}^{3}\right)$ & Kadar Air (\%) & berat jenis \\
\hline 1 & & 150.30 & 133.38 & 188.93 & $12.69 \%$ & 0.7060 \\
\hline 2 & & 149.94 & 134.05 & 188.21 & $11.85 \%$ & 0.7122 \\
\hline 3 & Suhu $80^{\circ} \mathrm{C}$ & 148.97 & 131.90 & 187.32 & $12.94 \%$ & 0.7041 \\
\hline 4 & & 146.29 & 130.34 & 188.09 & $12.24 \%$ & 0.6930 \\
\hline 5 & & 147.20 & 131.10 & 187.02 & $12.28 \%$ & 0.7010 \\
\hline & Rata-Rata & 148.54 & 132.15 & 187.91 & $12.40 \%$ & 0.7033 \\
\hline 6 & & 150.39 & 134.45 & 189.02 & $11.86 \%$ & 0.7113 \\
\hline 7 & & 150.98 & 134.59 & 188.01 & $12.18 \%$ & 0.7159 \\
\hline & Suhu $100{ }^{\circ} \mathrm{C}$ & 151.43 & 134.48 & 189.04 & $12.60 \%$ & 0.7114 \\
\hline 9 & & 150.39 & 134.74 & 189.10 & $11.61 \%$ & 0.7125 \\
\hline 10 & & 150.29 & 134.30 & 187.03 & $11.91 \%$ & 0.7181 \\
\hline & Rata-Rata & 150.70 & 134.51 & 188.44 & $12.03 \%$ & 0.7138 \\
\hline 11 & & 151.79 & 135.26 & 184.90 & $12.22 \%$ & 0.7315 \\
\hline 12 & & 152.98 & 136.44 & 186.02 & $12.12 \%$ & 0.7335 \\
\hline & Suhu $120^{\circ} \mathrm{C}$ & 150.02 & 134.56 & 184.39 & $11.49 \%$ & 0.7298 \\
\hline 14 & & 149.17 & 134.46 & 185.32 & $10.94 \%$ & 0.7256 \\
\hline 15 & & 149.92 & 133.36 & 185.56 & $12.42 \%$ & 0.7187 \\
\hline & Rata-Rata & 150.78 & 134.82 & 185.24 & $11.84 \%$ & 0.7278 \\
\hline 16 & & 149.30 & 134.62 & 187.02 & $10.90 \%$ & 0.7198 \\
\hline 17 & & 148.94 & 133.98 & 188.03 & $11.17 \%$ & 0.7125 \\
\hline & Suhu $130^{\circ} \mathrm{C}$ & 149.97 & 134.44 & 187.10 & $11.55 \%$ & 0.7185 \\
\hline 19 & & 149.29 & 133.02 & 188.02 & $12.23 \%$ & 0.7075 \\
\hline 20 & & 149.20 & 134.00 & 187.03 & $11.34 \%$ & 0.7165 \\
\hline & Rata-Rata & 149.34 & 134.01 & 187.44 & $11.44 \%$ & 0.7150 \\
\hline 21 & & 150.01 & 134.80 & 186.00 & $11.28 \%$ & 0.7247 \\
\hline 22 & & 150.48 & 134.72 & 185.12 & $11.70 \%$ & 0.7277 \\
\hline & Suhu $140{ }^{\circ} \mathrm{C}$ & 149.97 & 134.94 & 186.32 & $11.14 \%$ & 0.7242 \\
\hline 24 & & 152.29 & 136.98 & 187.00 & $11.18 \%$ & 0.7325 \\
\hline 25 & & 152.20 & 136.70 & 185.32 & $11.34 \%$ & 0.7376 \\
\hline & Rata-Rata & 150.99 & 135.63 & 185.95 & $11.33 \%$ & 0.7294 \\
\hline
\end{tabular}

\subsection{Kadar Air Spesimen Pengujian Lentur}

Hasil perhitungan kadar air bambu laminasi rata - rata berkisar dari $11.12 \%-12.19 \%$. Kadar air rata-rata laminasi bambu terendah pada suhu kempa $140^{\circ} \mathrm{C}$ sebesar $11.12 \%$ dan tertinggi pada suhu kempa $80^{\circ} \mathrm{C}$ sebesar $12.19 \%$ dengan lama waktu kempa 15 menit.

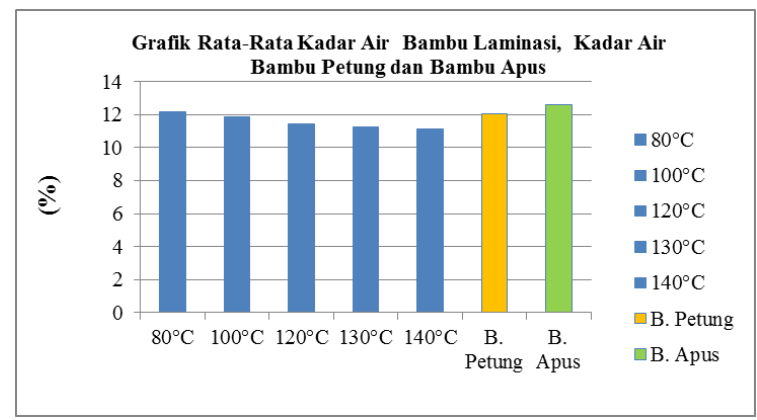

Gambar 3.Nilai rata - rata Kadar Air Pengujian Lentur

Hasil pada gambar 3 menunjukan bahwa tingginya suhu berpengaruh nyata terhadap kadar air laminasi. Laminasi dengan suhu pengempaan $80^{\circ} \mathrm{C}$ jauh berbeda nyata dengan laminasi suhu kempa $100^{\circ} \mathrm{C}, 120^{\circ} \mathrm{C}, 130^{\circ} \mathrm{C}$, dan $140^{\circ} \mathrm{C}$. Laminasi dengan suhu kempa $130^{\circ} \mathrm{C}$ tidak jauh berbeda dengan suhu $140^{\circ} \mathrm{C}$. Hal ini mengidikasikan bahwa peningkatan suhu lebih efektif mengeluarkan uap air yang terdapat pada partikel selama proses pengempaan.

\section{Tabel 2.Nilai Kadar Air Laminasi Bambu}

\begin{tabular}{|c|c|c|c|c|c|c|}
\hline \multicolumn{7}{|c|}{ Ukuran Lamina $(760 \times 50 \times 50 \mathrm{~mm})$} \\
\hline No & Kode Uji & Berat Awal (gr) & berat akhir (gr) & Volume $\left(\mathrm{cm}^{3}\right)$ & Kadar Air $(\%)$ & Berat Jenis \\
\hline 1 & & 1280.94 & 1140.44 & 1699.21 & $12.32 \%$ & 0.6712 \\
\hline 2 & & 1290.90 & 1149.58 & 1670.32 & $12.29 \%$ & 0.6882 \\
\hline 3 & Suhu $80{ }^{\circ} \mathrm{C}$ & 1289.21 & 1148.44 & 1650.89 & $12.26 \%$ & 0.6956 \\
\hline 4 & & 1309.08 & 1164.28 & 1690.32 & $12.44 \%$ & 0.6888 \\
\hline 5 & & 1289.90 & 1155.58 & 1699.21 & $11.62 \%$ & 0.6801 \\
\hline & Rata-Rata & 1292.01 & 1151.66 & 1681.99 & $12.19 \%$ & 0.6848 \\
\hline 6 & & 1279.32 & 1143.58 & 1690.37 & $11.87 \%$ & 0.6765 \\
\hline 7 & & 1318.94 & 1174.92 & 1629.21 & $12.26 \%$ & 0.7212 \\
\hline 8 & Suhu $100{ }^{\circ} \mathrm{C}$ & 1279.12 & 1140.37 & 1699.56 & $12.17 \%$ & 0.6710 \\
\hline 9 & & 1279.12 & 1141.61 & 1630.22 & $12.05 \%$ & 0.7003 \\
\hline 10 & & 1299.94 & 1170.98 & 1630.09 & $11.01 \%$ & 0.7184 \\
\hline & Rata-Rata & 1291.29 & 1154.29 & 1655.89 & $11.87 \%$ & 0.6975 \\
\hline 11 & & 1297.79 & 1160.11 & 1604.11 & $11.87 \%$ & 0.7232 \\
\hline 12 & & 1290.17 & 1153.41 & 1610.71 & $11.86 \%$ & 0.7161 \\
\hline 13 & Suhu $120^{\circ} \mathrm{C}$ & 1287.44 & 1152.32 & 1601.11 & $11.73 \%$ & 0.7197 \\
\hline 14 & & 1290.90 & 1164.28 & 1610.89 & $10.88 \%$ & 0.7228 \\
\hline 15 & & 1279.12 & 1154.02 & 1600.87 & $10.84 \%$ & 0.7209 \\
\hline & Rata-Rata & 1289.08 & 1156.83 & 1605.538 & " $11.43 \%$ & 0.7205 \\
\hline 16 & & 1299.94 & 1170.88 & 1618.21 & $11.02 \%$ & 0.7236 \\
\hline 17 & & 1279.15 & 1140.44 & 1608.89 & $12.16 \%$ & 0.7088 \\
\hline 18 & Suhu $130^{\circ} \mathrm{C}$ & 1279.22 & 1149.27 & 1634.11 & $11.31 \%$ & 0.7033 \\
\hline 19 & & 1289.21 & 1165.35 & 1607.56 & $10.63 \%$ & 0.7249 \\
\hline 20 & & 1279.38 & 1150.58 & 1594.11 & $11.19 \%$ & 0.7218 \\
\hline & Rata-Rata & 1285.38 & 1155.30 & 1612.576 & $11.26 \%$ & 0.7165 \\
\hline 21 & & 1309.29 & 1175.55 & 1630.09 & $11.38 \%$ & 0.7212 \\
\hline 22 & & 1279.21 & 1150.89 & 1581.11 & $11.15 \%$ & 0.7279 \\
\hline 23 & Suhu $140^{\circ} \mathrm{C}$ & 1274.90 & 1149.27 & 1600.89 & $10.93 \%$ & 0.7179 \\
\hline 24 & & 1293.89 & 1165.35 & 1600.11 & $11.03 \%$ & 0.7283 \\
\hline 25 & & 1279.12 & 1149.50 & 1609.87 & $11.28 \%$ & 0.7140 \\
\hline & Rata-Rata & 1287.28 & 1158.11 & 1604.414 & $11.15 \%$ & 0.7219 \\
\hline
\end{tabular}

\subsection{Berat Jenis}

Pada Biro Klasifikasi Indonesia kapal kayu menetapkan standar kelas kapal kayu $0.60-0.90$ masuk dalam kelas kuat II.

Untuk kerapatan kayu antara $0.55-0.72$ $\mathrm{gr} / \mathrm{cm}^{3}$, digologkan kedalam kayu berat.Kerapatan Bambu petung 0.78, bambu petung 0.67 menggunakan perekat phenol pormaldyhde.

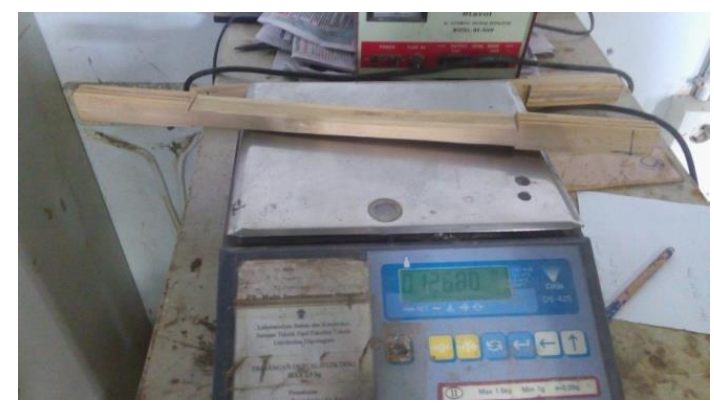

Gambar 4. Proses Menghitung Berat Laminasi Bambu Menggunakan Timbangan 


\subsection{Berat Jenis Spesimen Pengujian Tarik}

Hasil berat jenis laminasi bambu pada table 4.1 memiliki rata - rata yang diperoleh berkisar dari $0.7033 \mathrm{gr} / \mathrm{cm}^{3}-0.7294 \mathrm{gr} / \mathrm{cm}^{3}$ seperti terlihat pada table 4.1. Nilai berat jenis terendah pada laminasi bambu dengan suhu kempa $80^{\circ} \mathrm{C}$ sebesar $0.7033 \mathrm{gr} / \mathrm{cm}^{3}$ dan tertinggi dengan suhu kempa $140^{\circ} \mathrm{C}$ sebesar $0.7294 \mathrm{gr} / \mathrm{cm}^{3}$.

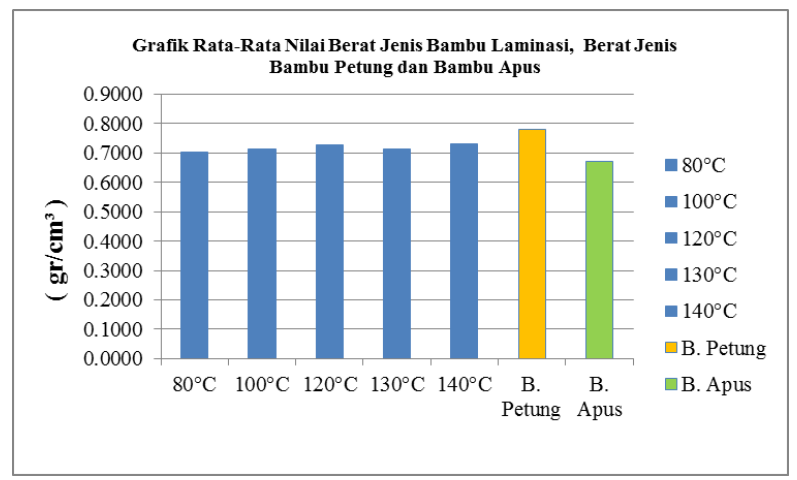

Gambar 5. Nilai rata - rata Berat Jenis Spesimen Pengujian

Pengaruh pengempaan berpengaruh nyata pada terhadap berat jenis laminasi, dimana berat jenis laminasi yang dikempa pada suhu $100^{\circ} \mathrm{C}$, $120^{\circ} \mathrm{C}, 130^{\circ} \mathrm{C}$ dan $140^{\circ} \mathrm{C}$ tidak jauh berbeda, tetapi berbeda nyata dengan laminasi yang dikempa pada suhu $80^{\circ} \mathrm{C}$. Hal ini mengidikasikan bahwa suhu yang dibutuhkan oleh perekat phenol formaldehyde untuk dapat bereaksi dengan baik pada suhu sekitar $120^{\circ} \mathrm{C}$, penambahan suhu pada diatas sudah tidak efektif lagi. Ini sesuai dengan penelitian untuk perekatan panas $115-150^{\circ} \mathrm{C}$.

\subsection{Berat Jenis Spesimen Pengujian Lentur}

Hasil berat jenis laminasi bambu pada grafik 4.2 memiliki rata - rata yang diperoleh berkisar dari $0.6848 \mathrm{gr} / \mathrm{cm}^{3}-0.7249 \mathrm{gr} / \mathrm{cm}^{3}$ seperti terlihat pada gambar 4.4.nilai berat jenis terendah pada laminasi bambu dengan suhu kempa $80^{\circ} \mathrm{C}$ dan tertinggi dengan suhu kempa $140^{\circ} \mathrm{C}$.

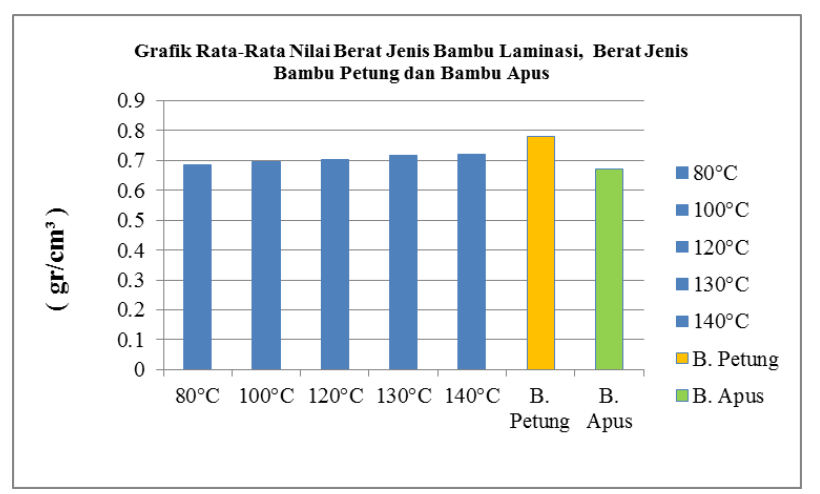

KAPAL, Vol. 14, No. 1 Januari 2017
Gambar 6. Nilai rata-rata Berat Jenis Spesimen Pengujian

Pengaruh pengempaan berpengaruh nyata pada terhadap berat jenis laminasi, dimana berat jenis laminasi yang dikempa pada suhu $100^{\circ} \mathrm{C}$, $120^{\circ} \mathrm{C}, 130^{\circ} \mathrm{C}$ dan $140^{\circ} \mathrm{C}$ tidak jauh berbeda, tetapi berbeda nyata dengan laminasi yang dikempa pada suhu $80^{\circ} \mathrm{C}$. Hal ini mengidikasikan bahwa suhu yang dibutuhkan oleh perekat Phenol formaldehyde untuk dapat bereaksi dengan baik pada suhu sekitar $120^{\circ} \mathrm{C}$, Penambahan suhu pada diatas sudah tidak efektif lagi. Ini sesuai dengan penelitian untuk perekatan panas $115-150^{\circ} \mathrm{C}$.

\subsection{Pengujian Tarik}

Pengujian Tarik adalah pengujian yang dilakukan dengan menggunakan alat uji tari "Universal Testing Machine".Pengujian ini bertujuan untuk mendapatkan nilai kuat Tarik.

Tabel 3.Nilai Kuat Tarik Laminasi Bambu

\begin{tabular}{|c|c|c|c|c|c|c|c|}
\hline Variasi Laminasi & Spesimen & $\mathrm{P} \max (\mathrm{N})$ & $\begin{array}{c}\sigma \\
\max (\mathrm{Mpa})\end{array}$ & $\begin{array}{c}\sigma \\
\text { Rata -rata } \\
(\mathrm{Mpa})\end{array}$ & $\begin{array}{l}\Delta \boldsymbol{\ell} \\
(\mathrm{mm})\end{array}$ & $\varepsilon$ & $\varepsilon$ Rata - rata \\
\hline \multirow{5}{*}{ Suhu $80 \mathrm{C}$} & 1 & 21407.54 & 85.63 & \multirow{5}{*}{85.45} & 3.0 & 0.0065 & \multirow{5}{*}{0.0067} \\
\hline & 2 & 21101.39 & 84.41 & & 3.0 & 0.0065 & \\
\hline & 3 & 20958.57 & 83.83 & & 3.0 & 0.0065 & \\
\hline & 4 & 21591.20 & 86.36 & & 3.0 & 0.0065 & \\
\hline & 5 & 21754.46 & 87.02 & & 3.5 & 0.0076 & \\
\hline \multirow{5}{*}{ Suhu $100 \mathrm{C}$} & 1 & 22547.15 & 90.19 & \multirow{5}{*}{88.85} & 3.0 & 0.0065 & \multirow{5}{*}{0.0065} \\
\hline & 2 & 22913.45 & 91.65 & & 2.5 & 0.0054 & \\
\hline & 3 & 22064.28 & 88.26 & & 3.5 & 0.0076 & \\
\hline & 4 & 22193.56 & 88.77 & & 3.0 & 0.0065 & \\
\hline & 5 & 21344.39 & 85.38 & & 3.0 & 0.0065 & \\
\hline \multirow{5}{*}{ Suhu $120 \mathrm{C}$} & 1 & 24787.43 & 99.15 & \multirow{5}{*}{97.84} & 2.5 & 0.0054 & \multirow{5}{*}{0.0061} \\
\hline & 2 & 24240.18 & 96.96 & & 3.0 & 0.0065 & \\
\hline & 3 & 24621.77 & 98.49 & & 3.0 & 0.0065 & \\
\hline & 4 & 24435.30 & 97.74 & & 2.5 & 0.0054 & \\
\hline & 5 & 24215.31 & 96.86 & & 3.0 & 0.0065 & \\
\hline \multirow{5}{*}{ Suhu $130 \mathrm{C}$} & 1 & 23829.27 & 95.32 & \multirow{5}{*}{95.40} & 2.5 & 0.0054 & \multirow{5}{*}{0.0056} \\
\hline & 2 & 23799.51 & 95.20 & & 2.5 & 0.0054 & \\
\hline & 3 & 23851.75 & 95.41 & & 2.8 & 0.0061 & \\
\hline & 4 & 23820.59 & 95.28 & & 2.5 & 0.0054 & \\
\hline & 5 & 23952.83 & 95.81 & & 2.5 & 0.0054 & \\
\hline \multirow{5}{*}{ Suhu $140 \mathrm{C}$} & 1 & 24516.97 & 98.07 & \multirow{5}{*}{96.63} & 2.5 & 0.0054 & \multirow{5}{*}{0.0050} \\
\hline & 2 & 24561.10 & 98.24 & & 2.6 & 0.0057 & \\
\hline & 3 & 23105.38 & 92.42 & & 2.0 & 0.0043 & \\
\hline & 4 & 24910.00 & 99.64 & & 2.3 & 0.0050 & \\
\hline & 5 & 23688.59 & 94.75 & & 2.0 & 0.0043 & \\
\hline
\end{tabular}

dimana $\boldsymbol{\Delta} \boldsymbol{\ell}$ adalah pertambahan panjang $(\mathrm{mm}), \boldsymbol{\varepsilon}$ adalah Elongation / Regangan, $\mathrm{P}_{\max }$ adalah besar gaya pengujian $(\mathrm{N})$ dan $\boldsymbol{\sigma}_{\max }$ adalah tegangan tarik maksimum (Mpa).

Nilai kekuatan Tarik laminasi rata - rata yang dihasilkan berkisar dari 85.45 Mpa - 97.84 Mpa. Nilai kekuatan Tarik laminasi tertinggi pada suhu kempa $120^{\circ} \mathrm{C}$ sebsar $85.45 \mathrm{Mpa}$ dan terendah pada laminasi dengan suhu kempa $80^{\circ} \mathrm{C}$ sebesar 97.84 Mpa.

Hasil analisa memeperlihatkan bahwa tingginya suhu berpengaruh nyata terhadap kekuatan Tarik laminasi bambu. Pada laminasi yang dikempa pada suhu $120^{\circ} \mathrm{C}$ dan $140^{\circ} \mathrm{C}$ tidak 
berbeda nyata, hal ini terjadi karena laminasi yang dihasilkan pada pengempaan $120^{\circ} \mathrm{C}, 130^{\circ} \mathrm{C}, 140^{\circ} \mathrm{C}$ perekat yang digunakan sudah mencapai suhu yang dibutuhkan agar perekat menempel secara sempurna. Dari penelitian yang dilakuan kekuatan Tarik bambu petung kering oven sebesar $116 \mathrm{Mpa}$ dan bambu apus $55 \mathrm{Mpa}$.

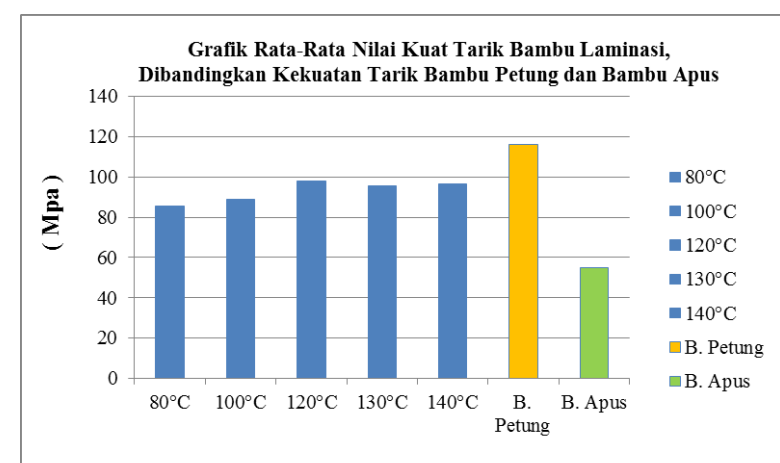

Gambar 7. Nilai rata - rata Kuat Tarik Spesimen Pengujian Tarik

\subsection{Pengujian Lentur}

Pada data hasil pengujian tekuk diambil dari sample hasil yang menunjukan besarnya harga gaya beban max saat menekuk. Pengujian tekuk tersebut didapatkan harga gaya beban $\left(\mathrm{P}_{\text {beban }}\right)$ dan tegangan lentur $\max \left(\boldsymbol{\sigma}_{\max }\right)$. dari tiap variable pengujian terdapat nilai terdapat lima sample specimen yang masing - masing sample berbeda beda suhu kempanya.

Tabel 4. Nilai Kuat Lentur Laminasi Bambu

\begin{tabular}{|c|c|c|c|c|c|c|}
\hline $\begin{array}{c}\text { Variasi } \\
\text { Laminasi }\end{array}$ & Spesimen & $\begin{array}{c}\mathrm{P} \max \\
(\mathrm{N})\end{array}$ & $\begin{array}{l}\text { MOE } \\
\text { (Mpa) }\end{array}$ & $\begin{array}{c}\text { MOE } \\
\text { Rata -rata } \\
(\mathrm{Mpa})\end{array}$ & $\begin{array}{l}\text { MOR } \\
\text { (Mpa) }\end{array}$ & $\begin{array}{c}\text { MOR } \\
\text { Rata -rata } \\
(\mathrm{Mpa})\end{array}$ \\
\hline \multirow{5}{*}{$80^{\circ} \mathrm{C}$} & 1 & 12441.3 & 8224.4 & \multirow{5}{*}{8327.3} & 89.6 & \multirow{5}{*}{90.82} \\
\hline & 2 & 12432.8 & 8150.2 & & 89.5 & \\
\hline & 3 & 12840.6 & 8488.3 & & 92.5 & \\
\hline & 4 & 12831.1 & 8514.6 & & 92.4 & \\
\hline & 5 & 12522.2 & 8258.9 & & 90.2 & \\
\hline \multirow[t]{2}{*}{. } & 1 & 12940.6 & 8667.2 & \multirow[t]{2}{*}{ 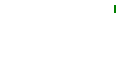 } & 93.2 & \multirow{5}{*}{96.08} \\
\hline & 2 & 13317.6 & 8703.8 & & 95.9 & \\
\hline \multirow[t]{5}{*}{$100^{\circ} \mathrm{C}$} & 3 & 13506.0 & 8907.8 & \multirow[t]{3}{*}{8867.2} & 97.2 & \\
\hline & 4 & 12988.8 & 8699.5 & & 93.5 & \\
\hline & 5 & 13971.9 & 9357.9 & & 100.6 & \\
\hline & 1 & 14225.0 & 9639.5 & \multirow[t]{2}{*}{ 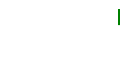 } & 102.4 & \multirow{5}{*}{100.39} \\
\hline & 2 & 13718.9 & 9174.2 & & 98.8 & \\
\hline \multirow[t]{5}{*}{$120^{\circ} \mathrm{C}$} & 3 & 13957.2 & 9435.9 & \multirow[t]{3}{*}{9476.1} & 100.5 & \\
\hline & 4 & 13983.7 & 9720.0 & & 100.7 & \\
\hline & 5 & 13833.2 & 9410.9 & & 99.6 & \\
\hline & 1 & 13825.0 & 9049.1 & \multirow[t]{2}{*}{ " } & 99.5 & \multirow{5}{*}{100.27} \\
\hline & 2 & 13718.9 & 9103.8 & & 98.8 & \\
\hline \multirow[t]{5}{*}{. $130^{\circ} \mathrm{C}$} & 3 & 13958.2 & 9663.4 & \multirow[t]{3}{*}{9438.6} & 100.5 & \\
\hline & 4 & 14293.7 & 10032.3 & & 102.9 & \\
\hline & 5 & 13833.2 & 9344.7 & & 99.6 & \\
\hline & 1 & 14438.8 & 9323.7 & \multirow{5}{*}{9517.9} & 104.0 & \multirow{5}{*}{101.59} \\
\hline & 2 & 14039.3 & 9536.1 & & 101.1 & \\
\hline \multirow[t]{3}{*}{$140^{\circ} \mathrm{C}$} & 3 & 14374.6 & 9951.6 & & 103.5 & \\
\hline & 4 & 13831.4 & 9178.4 & & 99.6 & \\
\hline & 5 & 13866.4 & 9599.8 & & 99.8 & \\
\hline
\end{tabular}

Dimana MOE adalah Modulus Elastisitas (Mpa), MOR adalah Modulus Of Repture ( Mpa). $\mathrm{P}_{\max }$ adalah besar gaya pengujian (N) $\boldsymbol{\sigma}_{\max }$ adalah tegangan tarik max (Mpa)

\subsection{Nilai Keteguhan Patah (MOR)}

Nilai keteguhan patah laminasi bambu yang dihasilkan berkisar dari $90.82 \mathrm{Mpa}-101.59 \mathrm{Mpa}$. Nilai keteguhan patah laminasi bambu tertinggi pada suhu kempa $140^{\circ} \mathrm{C}$ sebesar $101.59 \mathrm{Mpa}$ dan terendah pada laminasi bambu pada suhu kempa $80^{\circ} \mathrm{C}$ sebesar $90.82 \mathrm{Mpa}$. faktor suhu kempa sangat berpengaruh terhadap keteguhan patah laminasi bambu. Dimana laminasi bambu dengan suhu kempa $80^{\circ} \mathrm{C}$ berbeda dengan lainya. Sementara laminasi yang dikempa pada suhu $120^{\circ} \mathrm{C}$ dan $140^{\circ} \mathrm{C}$ tidak berbeda. Hal ini terjadi karena suhu yang dibutuhkan untuk mengeraskan perekat sudah tercapai sehingga menghasi kekuatan rekat yang baik.

Pengujian dilakukan setelah kering udara 10 $\%$ - $20 \%$ memiliki kekuatan lentur untuk bambu petung sebesar $117 \mathrm{Mpa}$, sedangkan bambu apus memiliki rata - rata kuat lentur sebesar $80 \mathrm{Mpa}$.

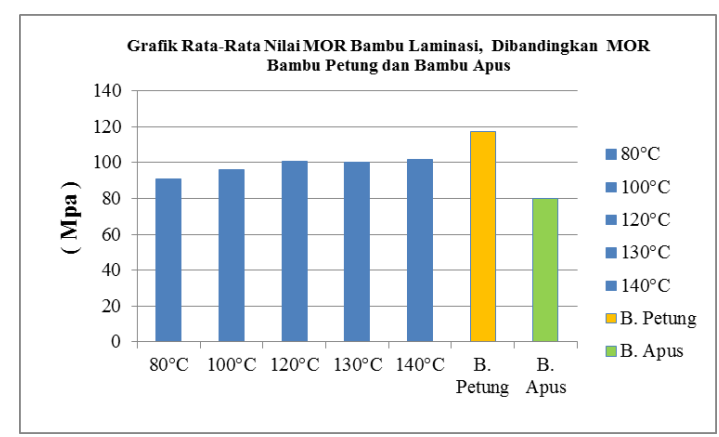

Gambar 8. Nilai rata - rata MOR

\subsection{Nilai Keteguhan Modulus Elastisitas (MOE)}

Nilai Modulus Elastisitas laminasi bambu yang dihasilkan berkisar dari 8327.3 Mpa - 9517.9 Mpa. Nilai keteguhan patah laminasi bambu tertinggi pada suhu kempa $140^{\circ} \mathrm{C}$ sebesar 9517.9 Mpa dan terendah pada laminasi bambu pada suhu kempa $80^{\circ} \mathrm{C}$ sebesar $8327.3 \mathrm{Mpa}$. Faktor pengaruh suhu kempa sangat berpengaruh terhadap keteguhan patah laminasi bambu. Dimana laminasi bambu dengan suhu kempa $80^{\circ} \mathrm{C}$ berbeda dengan lainya. Sementara laminasi yang dikempa pada suhu $120^{\circ} \mathrm{C}$ dan $140^{\circ} \mathrm{C}$ tidak berbeda. Hal ini terjadi karena suhu yang dibutuhkan untuk mengeraskan perekat sudah tercapai sehingga menghasi kekuatan rekat yang baik.

Pengujian dilakukan setelah kering udara 10 $\%$ - $20 \%$ memiliki kekuatan lentur untuk bambu petung sebesar $10329 \mathrm{Mpa}$, sedangkan bambu apus memiliki rata - rata kuat lentur sebesar $5751 \mathrm{Mpa}$. 


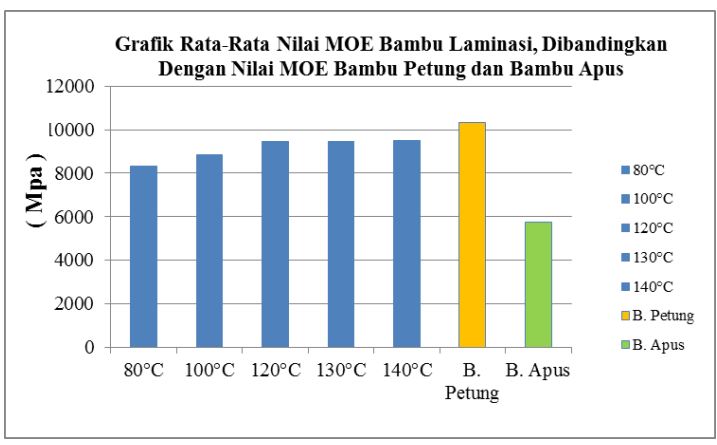

Gambar 9. Nilai rata - rata MOE

\subsection{Perbandingan Hasil Pengujian Dengan Syarat Bahan Kapal Kayu Dari Biro Klasifikasi Indonesia (BKI)}

Berdasarkan kuat kelas kapal kayu menurut peraturan Biro Klasifikasi Indonesia 1996 didapatkan persyaratan sebagai berikut:

\section{Tabel 5 Nilai Kuat Kelas Kapal Kayu}

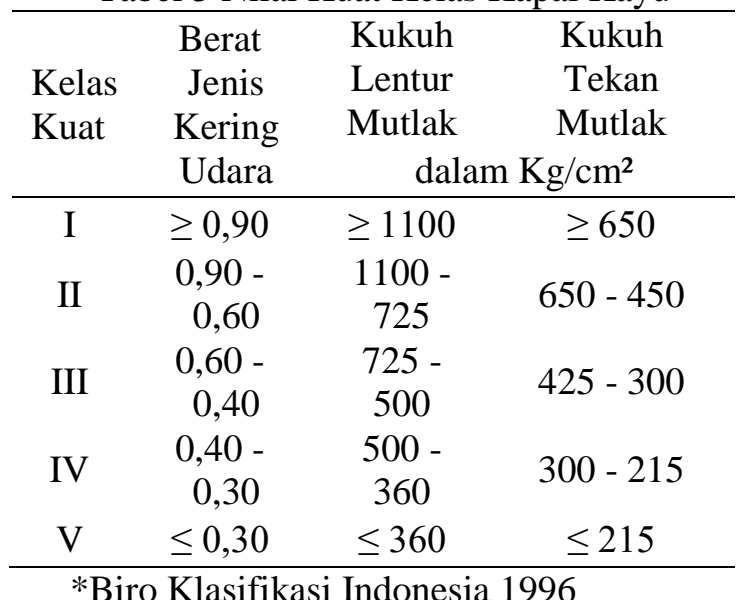

*Biro Klasifikasi Indonesia 1996

Untuk membuat komponen - komponen pada kapal kayu secara umum dapat mengunakan kayu seperti kayu Rengas.Kayu Rengas menurut Biro Klasifikasi Indonesia 1996 masuk dalam Kelas Kuat II dan Kelas Awet II.Kayu Rengas sering digunakan untuk membuat komponen kapal seperti gading, galar, kulit, papan geladak, balok geladak.

Berdasarkan hasil pengujian nilai berat jenis laminasi bambu yang dihasilkan untuk pengujian tarik berkisar antara $0.7033-0.7294$. Sedangkan nilai berat jenis laminasi bambu untuk pengujian lentur berkisar antara $0.6848 \quad 0.7219$. Berdasarkan peraturan Biro Klasifikasi Indonesia Vol. VI tentang kapal kayu laminasi bambu petung dengan bambu apus masuk dalam kriteria Kelas Kuat II.

Nilai Modulus Of Repture laminasi bambu petung dengan bambu apus akibat perlakuan suhu kempa yang dihasilkan antara $90.82 \mathrm{Mpa}-101.59$ Mpa atau dikonversikan sesuai satuan $\mathrm{kg} / \mathrm{cm}^{2}$ menjadi $867.37 \mathrm{~kg} / \mathrm{cm}^{2}-1066.83 \mathrm{~kg} / \mathrm{cm}^{2}$. Dalam table 4.5 tentang kelas kuat kayu nilai Modulus Of
Repture laminasi bambu petung dengan bambu apus akibat pengaruh suhu kempa masuk kedalam Kelas Kuat II. Menurut peraturan Biro Klasifikasi Indonesia tentang klasifikasi dan konstruksi kapal kayu, bahwa kapal kayu dapat menggunakan kayu yang mempunyai kerapatan yang lebih rendah atau lebih tinggi tetapi diikuti dengan penambahan atau pengurangan dimensi sampai $30 \%$.

Dari hasil pengujian untuk balok laminasi bambu petung dengan bambu apus akibat pengaruh suhu kempa dapat direkomendasikan untuk dipakai dalam komponen kapal untuk penganti kayu, hal ini mengacu pada table jenis - jenis kayu yang dapat dipakai untuk pembuatan kapal sesuai dengan peraturan Biro Klasifikasi Indonesia Vol. VI tahun 1996.

Tabel 7.Rekomendasi Laminasi Bambu Untuk Komponen Menurut Biro Klasifikasi Indonesia Kapal Kayu 1996

\begin{tabular}{|c|c|c|c|}
\hline \multirow{2}{*}{ Pemakaian } & \multicolumn{2}{|c|}{ Kelas } & \multirow{2}{*}{ Berat Jenis } \\
\hline & Awet & Kuat & \\
\hline Gading & - & $\mathrm{V}$ & $\mathrm{v}$ \\
\hline Galar & $v$ & $\vee$ & $v$ \\
\hline Geladak & - & $v$ & $v$ \\
\hline Kulit & - & $\vee$ & $v$ \\
\hline Tiang Layar & 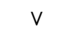 & $\vee$ & $\vee$ \\
\hline Rangka - rangka & - & $\vee$ & $\vee$ \\
\hline senta & - & $\vee$ & - \\
\hline Lunas & - & - & - \\
\hline Balok Geladak & - & $\vee$ & v \\
\hline Papan Geladak & - & $v$ & 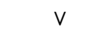 \\
\hline Linggi & - & $v$ & $\vee$ \\
\hline Dudukan Mesin & - & - & - \\
\hline Pondasi Mesin & - & $\vee$ & - \\
\hline Rumah Geladak & - & $v$ & $v$ \\
\hline Konstruksi Diatas Garis Air & $v$ & $v$ & $v$ \\
\hline Bantalan Poros Baling - Baling & - & - & - \\
\hline Balok Konstruksi Diatas Garis Air & 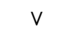 & $\vee$ & 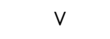 \\
\hline Papan & $v$ & $v$ & $\mathrm{v}$ \\
\hline
\end{tabular}

\section{KESIMPULAN}

Berdasarkan hasil perhitungan dan analisa dari penelitian ini, yang mengacu kepada hasil eksperimen dengan hasil pengujian tarik dan pengujian lentur maka dapat disimpulkan sebagai berikut:

Nilai tertinggi pada suhu kempa $140^{\circ} \mathrm{C}$ sebesar 101.59 Mpa untuk pengujian lentur. Terjadi Kenaikan Kuat Lentur sebesar $3.14 \%$ dibandingkan kuat lentur bambu petung dan bambu apus.Nilai tertinggi pada suhu kempa $120^{\circ} \mathrm{C}$ sebesar 97.84 Mpa untuk pengujian tarik. Terjadi kenaikan kuat tarik sebesar $10.43 \%$ di bandingkan dengan kuat tarik bambu petung dan bambu apus. Hal ini menunjukan laminasi bambu yang dikempa pada suhu $80^{\circ}$ mempunyai sifat fisik dan mekanik yang lebih rendah dibandingkan laminasi yang dikempa pada suhu $100^{\circ} \mathrm{C}, 120^{\circ} \mathrm{C}, 130^{\circ} \mathrm{C}$ dan $140^{\circ} \mathrm{C}$. 
Pengaruh suhu kempa mempengaruhi besar kecilnya kekuatan tarik dan kekuatan lentur karena makin tinggi proses pengempaan laminasi bambu memiliki kerapatan yang semakin baik. Suhu $120^{\circ} \mathrm{C}$ pada pengujian Tarik dan suhu $140^{\circ} \mathrm{C}$ pengujian lentur merupakan suhu yang optimal untuk jenis perekat phenol Formaldehida untuk mengeras dan matang.

Nilai Berat Jenis pengujian Tarik Tertinggi sebesar 0.7294, sedangkan berat jenis untuk pengujian lentur sebesar 0.7219. Dalam penelitian ini masuk dalam Kelas Kuat II. Mengacu pada Kelas Kuat Kayu Biro Klasifikasi Indonesia 1996 laminasi bambu direkomendasikan untuk pembuatan bagian - bagian kapal seperti gading, galar, kulit, papan geladak dan balok geladak dan papan.

\section{DAFTAR PUSTAKA}

[1] Widjaja, E. A., 1995. Plant resources of South-east Asia, no. 7: Bambus. Prosea, Bogor, Indonesia.

[2] Morisco, 1999, Rekayasa Bambu, Nafiri Offset, Yogyakarta.

[3] Prayitno, T.A., 1996. Perekatan Kayu, Fakultas Kehutanan, Universitas Gadjah Mada, Yogyakarta.

[4] Serrano, E. 2003. Mechanical performance and modelling of glulam. didalam: thelandersson S, Larsen hj, editor. timber engineering. west Sussex: Jhon Wiley dan Sons, ltd. hlm 67-79.

[5] Standar Nasional Indonesia (SNI), 1995. Metode Pengujian Kuat Tekan Kayu di Laboratorium, SNI 03-3958-1995, Indonesia.

[6] Standar Nasional Indonesia (SNI), 1994. Metode Pengujian Kuat Tekan Kayu di Laboratorium, SNI 03-3399-1994, Indonesia.

[7] A. A. Zul Zihni, P. Manik, B. A. Adietya, "Analisa Kekuatan Tekan dan Kekuatan Tarik Balok Laminasi Kayu Keruing Dan Bambu Petung Untuk Komponen Kapal Kayu", Jurnal Teknik Perkapalan, vol. 5, No. 1, 2017.

[8] P. Nugroho, P. Manik, B. A. Adietya, " Analisa Kekuatan Tekan dan Kekuatan Tarik Pada Balok Laminasi Kayu Meranti Merah dan Bambu Petung Untuk Komponen Kapal Kayu", Jurnal Teknik Perkapalan, vol. 5, No. $1,2017$.

[9] R. C. Arrahman, P. Manik, S. Jokosisworo, " Analisa Kekuatan Lentur dan Kekuatan Tarik Pada Balok Laminasi Bambu Petung dan Kayu Kelapa (Glugu) Untuk Komponen Kapal", Jurnal Teknik Perkapalan, vol. 5, No. $1,2017$.
[10]E. Juniawan, A. W. B. Santosa, S. Jokosisworo, "Analisa Kekuatan Sambungan Kayu Laban (Vitex Pinnata L.) Pada Konstruksi Gading Kapal Tradisional", Jurnal Teknik Perkapalan, vol. 3, No. 1, 2015. 